\title{
4-[18F]Fluoroglutamic Acid
}

National Cancer Institute

\section{Source}

National Cancer Institute. 4-[18F7Fluorog/utamic Acid. NCI Thesaurus. Code C157280.

A radioconjug ate composed of the radionuclide fluorine $\mathrm{F} 18$ conjug ated to L-glutamic acid, with potential imag ing activity upon positron emission tomography (PET). Upon intravenous administration, the glutamic acid moiety of 4-[18F]fluorog lutamic acid specifically binds to tumor cells and is preferentially taken up by tumor cells due to the higher metabolic activity and enhanced glutaminolytic pathway in these cells compared to normal, healthy cells. Upon internalization and PET, tumor cells can be imaged and assessed. Tumor cells use the amino acid glutamine for nutritional purposes necessary for energy production and growth; as tumor cells proliferate more rapidly than normal healthy cells, glutamine uptake is higher in certain cancer cells. 